\title{
BUDAYA SEKOLAH, MOTIVASI BELAJAR DAN MUTU PENDIDIKAN AGAMA ISLAM
}

\author{
Suprapto
}

\begin{abstract}
The fundamental problem in carrying out of religious education in the public and private secondary schools is the low quality of the religious education. The quality of religious education has not been optimum because of some crucial factors, such as: the inadequate competencies of teachers in understanding and developing extracurriculum, time limitedness for teachers in improving and developing school culture, besides the lack of tool and infrastructure availability both quantitatively and qualitatively. Another factor influencing the quality of religious education is related strongly to the problem of the model person (model teacher). In this case, any constructive pattern of culture-wubich strengthening religious morality model in the school is neicessary to be built to disseminate and cultivate religious values and norms effectively.
\end{abstract}

Keywords: the school culture, motivation, quality, religious education.

\section{PENDAHULUAN}

\section{A. Latar Belakang}

Pendidikan merupakan faktor penting dan menentukan dalam kehidupan suatu bangsa yang berbudaya. Kemajuan suatu bangsa sangat tergantung pada tingkat pendidikan yang diperolehnya. Sistem pendidikan nasional dilaksanakan untuk meningkatkan kehidupan bangsa yang bermutu baik dalam arti moral-spiritualmaupun mutu dalam arti intelektual-profesional.

Pendidikan agama merupakan

Drs. Suprapto, M.Pd adalah Peneliti pada Puslitbang Pendidikan Agama dan Keagamaan - Badan Litbang dan Diklat Departemen Agama RI bagian integtal dari sistem pendidikan nasional (UU Sisdiknas pasal 12) memiliki kontribusi yang besar dalam 
penanaman nilai-nilai moral spiritual dan perilaku keberagamaan peserta didik. Penanaman nilai-nilai keberagamaan peserta didik di sekolah dilakukan melalui pembelajaran pendidikan agama karena pendidikan agama berperan penting dalam pembentukan sikap dan perilaku peserta didik.

Salah satu masalah yang dihadapi dunia pendidikan saat ini adalah kekerasan di sekolah, yang dianggap oleh guru sebagai bagian dari upaya pendisiplinan siswa. Ini dibuktikan dengan masih adanya tindakan guru menghukum murid yang melanggar aturan sekolah dengan caracara yang mencederai fisik, emosi, dan mental anak. Misalnya, meminta anak berdiri di depan kelas, berdiri di bawah terik matahari, diteriaki atau menteriakinya serta menyuruh siswa membersihkan kamar mandi. Hukuman tersebut potensial menimbulkan perasaan tersiksa pada diri anak. Sekolah pun terkesan menjadi lembaga yang menakutkan, dan jauh dari nilai-nilai pengasuhan (Kompas: 23 Maret 2006).

Hasil penelitian Puslitbang Pendidikan Agama dan Keagamaan tahun 2002 tentang model penyelenggaraan pendidikan agama di sekolah umum menunjukan bahwa kualitas hasil pendidikan agama di sekolah umum masih diperdebatkan. Banyak masalah yang mengitarinya, di antaranya kualitas guru yang tidak memadai, waktu pertemuan terbatas, pandangan siswa yang menilai sama antara pendidikan agama dan pendidikan umum, lingkungan yang kurang mendukung terhadap pembelajaran pendidikan agama (terbatasnya sarana dan prasarana) dan sistem evaluasi yang lebih menekankan pada pengetahuan semata kurang menyentuh pada aspek sikap dan ketrampilan peserta didik. Disamping itu masih terdapatnya keluhan masyarakat terhadap kurang berhasilnya pengajaran pendidikan agama di sekolah karena masih terjadinya tawuran antar pelajar, perilaku menyimpang, penyalahgunaan obat terlarang dikalangan pelajar dan lain sebagainya. Meskipun diakui bahwa kurang berhasilnya pendidikan agama Islam di sekolah bukan semata-mata disebabkan oleh guru pendidikan agama akan tetapi juga oleh aspek lain seperti sarana prasarana, kurikulum, SDM dan lingkungan. Dalam kontek ini, sekolah belum mampu memerankan dirinya dalam menanamkan nilai, sikap dan perilaku peserta didik.

Temuan lain dalam evaluasi penyelenggaraan Pendidikan Agama Islam di Sekolah Dasar yang dilaksanakan Puslitbang Pendidikan Agama dan Keagamaan, tahun 2006, di antaranya: kegiatan mandiri siswa tidak dirancang berdasarkan pendalaman materi pembelajaran 
PAI, masih lemahnya penyiapan alat bantu dalam pembelajaran PAI dan GPAI kurang melakukan pengembangan ide siswa dalam pembelajaran. Dalam kerangka itu sekolah perlu mengembangkan materi pembelajaran PAI yang sesuai harapan siswa dengan didukung alat bantu pembelajaran PAI yang memadai.

Atas dasar uraian tersebut di atas, maka sekolah perlu mengembangkan budaya sekolah, seperti: kultur disiplin, rasa tanggungjawab, kejujuran, keikhlasan, berfikir rasional, ethos/motivasi belajar, kebiasaan memecahkan masalah secara rasional, dan sebagainya.

Budaya sekolah akan menumbuhkan motivasi belajar siswa menjadi manusia yang penuh optimis, berani tampil, berperilaku kooperatif dan mernupuk rasa tanggung jawab dan rasa kebersamaan siswa. Motivasi belajar siswa akan memberikan pengalaman bagi tumbuhkembangnya kecerdasan, ketrampilan, dan aktivitas siswa yang pada akhirnya berhubungan terhadap mutu pendidikan.

\section{B. Masalah Penelitian}

Studi ini difokuskan pada empat persoalan pokok, yaitu:

1. Apakah budaya sekolah berhubungan langsung terhadap motivasi belajar siswa pada mata pelajaran pendidikan agama Islam?

2. Apakah motivasi belajar siswa berhubungan langsung terhadap mutu pendidikan agama Islam?

3. Bagaimana budaya sekolah berhubungan secara tidak langsung terhadap mutu pendidikan agama Islam?

4. Bagaimana model pengembangan budaya sekolah?

\section{Tujuan Penelitian}

Penelitian ini bertujuan untuk:

1. Mengetahui seberapa besar hubungan budaya sekolah terhadap motivasi belajar siswa dalam pendidikan agama Islam.

2. Mengetahui seberapa besar hubungan motivasi belajar siswa terhadap mutu pendidikan agama Islam.

3. Mengetahui seberapa besar hubungan budaya sekolah terhadap mutu pendidikan agama Islam.

4. Mendeskripsikan model pengembangan budaya sekolah. 


\section{Kerangka Teoritik}

\section{Budaya Organisasi}

Dalam kerangka lebih luas budaya sekolah dapat dilihat sebagai bagian dari budaya organisasi. Menurut Nana Syaodih Sukmadinata, dkk., menyatakan bahwa sekolah sebagai lembaga pendidikan merupakan suatu organisasi yang memiliki struktur organisasi tertentu. ${ }^{1}$ Sehingga budaya sekolah kurang lebih sama dengan budaya organisasi.

Budaya "kultur" dapat didefinisikan sebagai kualitas kehidupan (the quality of life) dalam sebuah organisasi, termanifestasikan dalam aturan-aturan atau norma-norma, tata kerja (work habits), gaya kepemimpinan (operating styles of principals) seorang atasan maupun bawahan. ${ }^{2} \mathrm{Kualitas}$ kehidupan organisasi, baik yang terwujud dalam kebiasaan kerja maupun kepemimpinan dalam hubungan tersebut tumbuh dan berkembang berdasarkan spirit dan keyakinan tertentu yang dianut organisasi. Rober G. Owen dalam Budaya Organisasi dan Peningkatan Kinerja Perusabaan, mengemukakan definisi budaya adalah suatu sistem pembagian nilai dan kepercayaan yang berinteraksi dengan orang dalam suatu organisasi, struktur organisasi dan sistem kontrol yang menghasilkan norma perilaku. Lebih lanjut dikatakan bahwa budaya adalah suatu pola asumsi dasar yang diciptakan, ditemukan atau dikembangkan oleh kelompok tertentu sebagai pembelajaran untuk mengatasi masalah adaptasi eksternal dan integrasi internal yang resmi dan terlaksana dengan baik, oleh karena itu diajarkan/diwariskan kepada anggota-anggota baru sebagai cara yang tepat memahami, memikirkan, dan merasakan terkait dengan masalah-masalah tersebut. Organisasi adalah pengaturan personil guna memudahkan pencapaian beberapa tujuan yang telah ditetapkan melalui alokasi fungsi dan tanggung jawab. ${ }^{3}$ Pendapat lain menyatakan bahwa organisasi adalah kerjasama dua orang atau lebih, suatu sistem aktivitasaktivitas atau kekuatan-kekuatan yang dikoordinasikan secara sadar. Berdasarkan definisi tersebut maka yang dimaksud budaya organisasi adalah pokok penyelesaian masalah-masalah eksternal dan internal

\footnotetext{
1 Nana Syodih Sukmadinata, dkk. 2006. Pengendalian Mutu Pendidikan Sekolah Menengah : Konsep, Prinsip dan Intrumen. Jakarta: Penerbit Aditama, h. 48

${ }^{2}$ Hodge, BJ. Dan William P. Anthony. 1991. Organization Theory, Boston: Allyn and Bacon, Inc.,

3 Pabundu Tika. 2006. Budaya Organisasi dan Peningkatan Kinerja Perusahaan, Jakarta: Penerbit Bumi Aksara, h. 4
} 
yang pelaksanaannya dilakukan secara konsisten oleh suatu kelompok yang kemudian mewariskan kepada anggota-anggota baru sebagai cara yang tepat untuk memahami, memikirkan dan merasakan terhadap masalah-masalah. Pendapat lain menyatakan bahwa budaya organisasi adalah seperangkat asumsi dasar dan keyakinan yang dianut oleh anggota-anggota organisasi kemudian dikembangkan dan diwariskan guna mengatasi masalah-masalah adaptasi eksternal dan masalah integrasi internal. ${ }^{4}$

\section{Budaya Sekolah}

Sekolah sebagai suatu sistem memiliki tiga aspek pokok yang sangat berkaitan erat dengan mutu sekolah, yakni: proses belajar mengajar, kepemimpinan dan manajemen sekolah, serta kultur sekolah. Kultur merupakan pandangan hidup yang diakui bersama oleh suatu kelompok masyarakat, yang mencakup cara berfikir, berperilaku, bersikap, nilai yang tercermin baik dalam wujud fisik maupun abstrak. Kultur ini dapat dilihat sebagai perilaku, nilai-nilai, sikap hidup dan cara hidup untuk melakukan penyesuaian dengan lingkungan, dan sekaligus untuk memandang persoalan dan memecahkannya. ${ }^{5}$ Oleh karena itu suatu kultur secara alami akan diwariskan oleh satu generasi ke generasai berikutnya.

Budaya sekolah adalah kualitas kehidupan sekolah yang tumbuh dan berkembang berdasarkan spirit dan nilai-nilai tertentu yang dianut sekolah. Lebih lanjut dikatakan bahwa budaya sekolah adalah keseluruhan latar fisik, lingkungan, suasana, rasa, sifat, dan iklim sekolah yang secara produktif mampu memberikan pengalaman baik bagi bertumbuhkembangnya kecerdasan, ketrampilan, dan aktivitas siswa. Budaya sekolah dapat ditampilkan dalam bentuk hubungan kepala sekolah, guru, dan tenaga kependidikan lainnya bekerja, kedisiplinan, rasa tanggungjawab, berfikir rasional, motivasi belajar, kebiasaan memecahkan masalah secara rasional. ${ }^{6}$

Berdasarkan uraian tersebut di atas maka yang dimaksud budaya sekolah dalam penelitian ini adalah keseluruhan nilai-nilai dan norma-

\section{${ }^{4}$ lbid.}

${ }^{5}$ Loc. Cit.

${ }^{6}$ Direktorat Pendidikan Menengah Umum Ditjen Pendidikan Dasar dan Menengah Departemen Pendidikan Nasional. 2002. Pedoman Pengembanagan Kultur Sekolah. Jakarta: Penerbit School Reform, h. 14. 
norma yang dianut sekolah dengan indikator: visi, misi dan tujuan sekolah, etos belajar, integrasi, norma agama, norma hukum dan norma sosial.

\section{Motivasi Belajar}

Motivasi berasal dari kata movere yang artinya "menggerakan", motivasi adalah sesuatu yang membuat orang bertindak atau berperilaku dalam cara-cara tertentu. ${ }^{7}$ Herbert mengatakan bahwa motivasi adalah internal yang melalui keadaan tertentu itu keputusan perilaku dibuat dan tujuan-tujuan atau keinginan individu dicapai. ${ }^{8}$ Sementara itu Lutthans mengatakan bahwa motivasi adalah suatu proses yang dimulai dengan adanya kekurangan-kekurangan fisiologis atau psikologis atau kebutuhan yang menggerakan perilaku atau dorongan seseorang untuk mencapai tujuan. ${ }^{9}$ Barelson dan Steiner dalam Donnely, Gibson dan Ivancevich mendefinisikan motivasi sebagai usaha dari dalam yang digambarkan dengan keinginan, hasrat, dorongan dan sebagainya, ini berupa kondisi dalam (inner) yang menggerakan atau menghidupkan. ${ }^{11}$ Seseorang yang mempunyai motivasi cenderung bekerja keras, menyokong langkah-langkah kerja keras dan mengarahkan perilakunya kepada tujuan-tujuan penting. Motivasi memiliki tiga unsur kunci yaitu usaha, tujuan dan kebutuhan. ${ }^{11}$

Belajar adalah proses di mana tingkah laku ditimbulkan atau diubah melalui latihan atau pengamalan. ${ }^{12}$ Gagne dalam Purwanto berpendapat bahwa belajar terjadi apabila suatu situasi stimulus bersama dengan isi ingatan menghubungi siswa sedemikian rupa sehingga perbuatannya berubah dari waktu sebelumnya ke waktu sesudah ia mengalami situasi tersebut. Sementara Nasution mengatakan bahwa belajar pada dasarnya menambah kelakuan anak meliputi keseluruhan

${ }^{7}$ Michael Amstrong. 1999. Manajemen Sumber Daya Manusia. Terj. Haryanto. Jakarta: Gramedia, h. 65.

${ }^{8}$ Theodore T. Herbert. 1981. Dimensions of Organization Behavior. Macmillan Publishing co.,Inc., h. 220.

${ }^{9}$ Fred Luthans. 1995. Organization Behavior. Singapore: Mc Graw-Hill, h. 141.

10 James H. Donnely Jr. at al. 1984. Fundamentals of Management. Texas: Business Publication Inc., hh. 308-309.

"Nancy J. Adler, at al. 1995. Cross-Cultural Management. London: ButterwortHeinemann Ltd., h. 97.

12 Abu Ahmadi dan Widodo Supriyono. 1991. Psikologi Belajar. Jakarta: Penerbit Rineka Cipta, h. 119. 
pribadi anak dengan hasil yang diharapkan berupa pengetahuan, sikap, minat, penghargaan, norma-norma kecakapan dan lainnya.

Berdasarkan uraian di atas yang dimaksud motivasi belajar adalah dorongan pribadi siswa untuk mempelajari pendidikan agama Islam di sekolah dengan indikator: menyukai pembelajaran pendidikan agama Islam, tanggungjawab terhadap pembelajaran pendidikan agama Islam, mampu menyelesaikan tugas-tugas pembelajaran pendidikan agama Islam dan keiinginan siswa untuk menguasai pembelajaran pendidikan agama Islam.

\section{Mutu Pendidikan}

Masalah mutu dalam dunia pendidikan dapat berbentuk mutu lulusan, mutu pengajaran, bimbingan dan latihan dari guru, serta mutu profesionalisme dan kinerja guru. ${ }^{1.3}$ Mutu-mutu tersebut terkait dengan mutu manajerial para pimpinan pendidikan, keterbatasan dana, sarana dan prasarana, fasilitas pendidikan, media, sumber belajar, alat dan bahan latihan, budaya sekolah, lingkungan pendidikan, serta dukungan dari pihak-pihak yang terkait dengan pendidikan. Mutu adalah gambaran dan karakteristik menyeluruh dari barang atau jasa yang menunjukkan kemampuannya dalam memuaskan kebutuhan yang diharapkan atau yang tersirat (Depdiknas, 2001). Umaedi mendefinisikan mutu sebagai sifat-sifat yang dimiliki suatu benda/barang atau jasa yang secara keseluruhan memberi rasa puas kepada penerima atau penggunanya karena telah sesuai atau melebihi apa yang dibutuhkan dan diharapkan para pelanggannya. Dalam konteks pendidikan, mutu mengacu pada proses dan hasil pendidikan. Pada proses pendidikan, mutu pendidikan berkaitan dengan bahan ajar, metodologi, sarana dan prasarana, ketenagaan, pembiayaan, lingkungan dan sebagainya. Namun pada hasil pendidikan, mutu berkaitan dengan prestasi yang dicapai sekolah dalam kurun waktu tertentu. Prestasi tersebut dapat berupa hasil tes kemampuan akademik seperti ulangan umum, raport, ujian nasional dan prestasi non-akademik seperti prestasi di bidang olah raga, seni atau ketrampilan. ${ }^{14}$ Sedangkan Iik Nurul Paik dalam artikelnya: Mengharapkan Sekolab Makin Bermutu (Pikiran Rakyat:2004), kebermutuan pendidikan dapat

${ }^{13}$ Nana Syaodih. Op. Cit., h. 8

14 Umaedi, Manajemen Peningkatan Mutu Berbasis Sekola, Sebuah Pendekartan Baru dalam Pengelolaan Sekolah untuk peningkatan Mutu. dalam www.depdiknas, go.,id., Diakses 20 Pebruari 2006. 
dilihat dari: (1) aspek pelayanan penyelenggaraan pendidikannya (dimensi proses); (2) ketersediaan fasilitas sarana dan prasarana; (3) kuantitas dan kualitas tenaga kependidikan; (4) prestasi akademik siswa; (5) kepuasan dan kepercayaan orang tua pada sistem pendidikan; dan (6) kemampuan kompetensi lulusannya dalam kehidupan.

Pendapat lain menyatakan bahwa kualitas pendidikan umumnya dikaitkan dengan tinggi rendahnya prestasi yang ditunjukan dengan kemampuan siswa mencapai skor dalam tes dan kemampuan lulusan mendapatkan dan melaksanakan pekerjaan. ${ }^{15}$ Maka mutu pendidikan terkait dengan hasil belajar. Hasil belajar merupakan tingkah laku yang dapat dicapai dari suatu pengalaman dan biasanya mengarah kepada penguasaan pengetahuan, kecakapan dan kebiasaan. Amatembun mengatakan bahwa hasil belajar adalah nilai aktif dari seorang siswa yang dinilai melalui teknik evaluasi yang dapat digunakan sebagai petunjuk seberapa jauh materi pelajaran telah dikuasi oleh siswa. ${ }^{16}$ Sedangkan Nasution mengatakan bahwa hasil belajar ialah suatu perubahan yang terjadi pada individu yang belajar, bukan saja perubahan mengenai pengetahuan, tetapi juga untuk membentuk kecakapan, penghargaan dalam diri pribadi yang belajar. ${ }^{17}$ Selanjutnya dinyatakan bahwa hasil belajar nampak pada perubahan-perubahan tingkah laku yang secara tertulis dinyatakan dalam suatu pernyataan verbal melalui tujuan instruksional.

Berdasarkan uraian tersebut di atas yang dimaksud dengan mutu pendidikan dalam penelitian ini adalah hasil belajar yang menyangkut prestasi belajar yang dicapai siswa baik yang berhubungan dengan pengetahuan, sikap atau perilaku setelah mempelajari pendidikan agama Islam dalam kurun waktu tertentu/semester yang dinyatakan dalam bentuk nilai rapor/ semester.

\section{G. Metode Penelitian}

Penelitian dilakukan pada 6 propinsi, yaitu: Banten, Jawa Barat, Yogjakarta, Sumatera Barat, Kalimantan Selatan, dan Nusa Tenggara h.19

${ }^{115}$ Zamroni. 2000. Paradigma Pendidikan Masa Depan. Penerbit: Bigraf Publishing,

${ }^{16}$ Amatembun. 1981. Manajemen Kelas: Pemenuhan Guru dan Calon Guru. Bandung: Penerbit IIP, h. 272.

${ }^{17}$ Nasution S. 1994. Didaktik dan Azas-azas Mengajar. Bandung: Penerbit Bumi Aksara, Bandung, h. 9. 
Barat dengan menggunakan pendekatan kuantitatif dan metode survey yang ditunjang dengan kualitatif. Penelitian ini berangkat dari hipotesis bahwa tinggi rendahnya mutu pendidikan agama Islam di sekolah terkait dengan budaya sekolah yang dianut. Sedangkan pendekatan kedua dimaksudkan untuk mendeskrisikan tentang model pengembangan budaya sekolah dalam mewujudkan mutu pendidikan agama Islam.

Populasi penelitian adalah seluruh SMP pada 6 propinsi, yaitu: Banten, Jawa Barat, Yogjakarta, Sumatera Barat, Kalimantan Selatan, dan Nusa Tenggara Barat. Sampel penelitian diambil dengan teknik Purposive Sampling, dengan langkah berikut: 1) pada setiap propinsi dipilih 1 (satu) Kab/Kota; 2) dalam satu kab/kota ditetapkan 4 (empat) SMP, yaitu 2 Negeri dan 2 Swasta, dengan kriteria SMP yang berprestasi; 3) masing-masing SMP sasaran penelitian ditetapkan responden: 40 Siswa, 1 Kepala Sekolah dan 1 Guru Pendidikan Agama Islam. Berdasarkan kriteria tersebut ditetapkan sampel penelitian, berjumlah 960 siswa, 24 Kepala Sekolah dan 24 Guru Pendidikan Agama Islam.

Pengumpulan data dilakukan dengan menggunakan kuesioner, wawancara, observasi dan dokumentasi. Kuesioner digunakan untuk memperoleh data kuantitatif mengenai budaya sekolah yang dijaring melalui siswa. Sedangkan wawancara dilakukan dengan sejumlah informan yang terdiri dari kepala sekolah dan guru Pendidikan Agama Islam untuk mendapatkan data kualitatif. Selanjutnya observasi dipakai untuk mendapatkan data yang berhubungan kondisi lingkungan sekolah dan kehidupan siswa di sekolah.

Analisa data penelitian menggunakan analisis kuantitatif dan kualitatif. Untuk data kuantitatif menggunakan SPSS (Statistical Package for Social Sciences) Versi 11. Sedangkan untuk data kualitatif, analisisnya melalui intrepretasi data

\section{TEMUAN PENELITIAN DAN PEMBAHASAN}

\section{A. Hubungan Budaya Sekolah, Motivasi Belajar Terhadap Mutu Pendidikan}

\section{Hubungan Budaya Sekolah Terhadap Motivasi Belajar Siswa dalam} Pendidikan Agama Islam

Dari hasil analisis korelasi sederhana terhadap pasangan data penelitian antara variabel budaya sekolah $\left(X_{1}\right)$ dengan motivasi belajar (Y) menghasilkan koefisien korelasi product moment sebesar $\mathrm{r}_{\mathrm{y} 1}=$ 0,680 . Untuk uji keberartian koefisien korelasi disajikan pada tabel 1 berikut ini: 
Tabel 1: Uji Keberartian Koefisien Korelasi antara Budaya

Sekolah dengan Motivasi Belajar Siswa

\begin{tabular}{|c|c|c|c|c|c|}
\hline \multirow{2}{*}{ Deskripsi } & $r$ & $r^{2}$ & $t_{0}$ & \multicolumn{2}{|c|}{$t_{t}$} \\
\cline { 1 - 3 } & & & & $\bullet=5 \%$ & $\bullet=1 \%$ \\
\hline $\begin{array}{c}\text { Korelasi Antara } \\
X_{1} \text { dan } X_{2}\end{array}$ & 0,680 & 0,463 & 28,227 & 1,66 & 2,33 \\
\hline
\end{tabular}

Keterangan:

$\mathbf{r}=$ Koefesien korelasi

$r^{2}=$ Koefesien diterminasi/Kontribusi

$\mathrm{t}_{\mathrm{o}}=$ tobservasi

$t_{r}=t$ tabel

á = tingkat kepercayaan

**Koefisien korelasi sangat signifikan $\left(t_{\text {lir }}=28,227>t_{t a l)}=2,39\right)$

Berdasarkan uji keberartian korelasi antara pasangan skor budaya sekolah $\left(\mathrm{X}_{1}\right)$ dengan motivasi belajat $\left(\mathrm{X}_{2}\right)$ sebagaimana terlihat pada tabel. 1 diperoleh $t_{\text {hinung }}=28,227>t_{\text {tabel }}=2,33$ pada taraf signifikansi $\mathrm{a}=0,01$, jadi dapat disimpulkan bahwa koefisien korelasi $\mathbf{r}_{\mathrm{x} 2 !}=0,680$ sangat signifikan. Dengan demikian hipotesis yang menyatakan terdapat Hubungan positif budaya sekolah terhadap motivasi belajar diterima. $\mathrm{Hal}$ ini berarti semakin baik budaya sekolah maka semakin tinggi pula motivasi belajar siswa, sebaliknya semakin jelek budaya sekolah maka akan semakin rendah motivasi belajar siswa. Hasil analisis juga menunjukkan koefisien determinasinya sebesar 0,463 Ini berarti $46,3 \%$ varians motivasi belajar dijelaskan oleh variabel budaya sekolah.

\section{Hubungan Motivasi Belajar Terhadap Mutu Pendidikan Agama Islam}

Dari hasil analisis korelasi sederhana terhadap pasangan data penelitian antara variabel motivasi belajar $\left(\alpha_{2}\right)$ dengan hasil belajar PAI siswa (Y) menghasilkan koefisien korelasi product moment sebesar $\quad \mathbf{r}_{y 2}=0,281$ Untuk uji keberartian koefisien korelasi disajikan pada tabel 3 berikut ini.

Tabel 2: Uji Keberartian Koefisien Korelasi antara

Motivasi belajar dengan Hasil Belajar PAI Siswa

\begin{tabular}{|c|c|c|c|c|c|}
\hline \multirow{2}{*}{ Deskripsi } & \multirow{2}{*}{$r$} & \multirow{2}{*}{$r^{2}$} & \multirow{2}{*}{$t_{0}$} & \multicolumn{2}{|c|}{$t_{t}$} \\
\hline & & & & - $=5 \%$ & $\cdot=1 \%$ \\
\hline $\begin{array}{c}\text { Korelasi Antara } \\
X, \operatorname{dan} Y\end{array}$ & 0,281 & 0,079 & 8,912 & 1,66 & 2,33 \\
\hline
\end{tabular}

Koefisien korelasi sangat signifikan $\left(t_{\text {tht }}=8,912>t_{\text {fill }}=2,33\right)$ 
Berdasarkan uji keberartian korelasi antara pasangan skor motivasi belajar $\left(\mathrm{X}_{2}\right)$ dengan hasil belajar PAI siswa(Y) sebagaimana terlihat pada tabel. 2 diperoleh $t_{\text {hirung }}=8,912>\mathrm{t}_{\text {tabel }}=2,33$ pada taraf signifikansi $a=0,01$, jadi dapat disimpulkan bahwa koefisien korelasi $\mathbf{r}_{y 2}=0,281$ sangat signifikan. Dengan demikian hipotesis yang menyatakan terdapat hubungan positif motivasi belajar terhadap motivasi belajar diterima. Hal ini berarti motivasi belajar sangat berhubungan terhadap hasil belajar siswa, artinya ting gi rendahnya motivasi belajar sangat berhubungan terhadap tingginya hasil belajar PAI siswa, semakin tinggi motivasi belajar maka akan semakin tinggi hasil belajar PAI siswa sebaliknya semakin rendah motivasi belajat siswa maka akan semakin rendah pula hasil belajar pendidikan agama Islam siswa. Hasil analisis menunjukkan koefisien determinasinya sebesar 0,079 Ini berarti bahwa hanya 7,9\% varians hasil belajar PAI siswa dijelaskan oleh variabel motivasi belajar.

\section{Hubungan Budaya Sekolah Terbadap Hasil Belajar PAI siswa}

Dari hasil analisis korelasi sederhana terhadap pasangan data penelitian antara variabel budaya sekolah $\left(\mathrm{X}_{1}\right)$ dengan hasil belajar PAI siswa (Y) menghasilkan koefisien korelasi product moment sebesar $r_{y 1}=0,032$ Untuk uji keberartian koefisien korelasi disajikan pada tabel 2 berikut ini.

Tabel 3: Uji Keberartian Koefisien Korelasi antara Budaya

Sekolah dengan Hasil Belajar PAI Siswa

\begin{tabular}{|c|c|c|c|c|c|}
\hline \multirow{2}{*}{ Deskripsi } & $r$ & $r^{2}$ & $t_{0}$ & \multicolumn{2}{|c|}{$t_{t}$} \\
\cline { 5 - 6 } & & & & $\bullet=5 \%$ & $\bullet=1 \%$ \\
\hline $\begin{array}{c}\text { Korelasi Antara } \\
X_{1} \text { dan } Y\end{array}$ & 0,237 & 0,056 & 7,419 & 1,66 & 2,33 \\
\hline
\end{tabular}

$* *$ Koefisien korelasi sangat signifikan $\left(t_{\text {bit }}=7,419>t_{\text {rall }}=2,33\right)$

Berdasarkan uji keberartian korelasi antara pasangan skor budaya sekolah $\left(\mathrm{X}_{1}\right)$ dengan hasil belajar PAI siswa(Y) sebagaimana terlihat pada tabel.2 diperoleh $t_{\text {hitung }}=7,419>t_{\text {rabel }}=2,33$ pada taraf signifikansi $a=0,01$, jadi dapat disimpulkan bahwa koefisien korelasi $\mathbf{r}_{\mathrm{y} 1}=0,237$ sangat signifikan. Dengan demikian hipotesis yang menyatakan terdapat Hubungan positif budaya sekolah terhadap hasil belajar diterima. Hal ini berarti budaya sekolah sangat berhubungan terhadap hasil belajar siswa, artinya baik tidaknya budaya sekolah sangat berhubungan 
terhadap tingginya hasil belajar PAI siswa. Semakin baik budaya sekolah akan semakin tinggi hasil belajar, sebaliknya semakin kurang baik budaya sekolah maka akan semakin rendah hasil belajar pendidikan agama Islam. Hasil analisis menunjukkan koefisien determinasinya sebesar 0,056 Ini berarti bahwa 5,6\% varians hasil belajar PAI siswa dijelaskan oleh variabel budaya sekolah.

\section{B. Model Pengembangan Budaya Sekolah}

\section{Pengembangan Tataran Nilai-nilai}

a. Nilai-Nilai Keimanan dan Ketakwaan Siswa

Semangat siswa dalam menjalankan nilai-nilai keimanan dan ketakwaan cukup tinggi dan baik. Terbukti dari semua program dan pembiasaan yang bernuansa peningkatan imtak dapat berjalan dengan baik, terlihat dari kegiatan rutinitas religi, seperti shalat jum'at berjamaah di sekolah, peringatan hari-hari besar keagamaan, serta rutinitas shalat biasa di luar Jum'at secara berjamaah, baik itu di sekolah maupun dalam kehidupan sehari-hari. Semua ini tidak terlepas dari ketekunan para guru serta pembinaan imtak melalui program yang menyentuh kearah itu.

Namun meskipun demikian masih ada sebagian SMP, yang spirit dan nilai-nilai keagamaan serta ketakwaan para siswanya belum memuaskan, terlihat dalam penyelenggaraan kegiatan imtak. Seperti kehadiran para siswa yang tidak seluruhnya hadir bila tidak diperintahkan oleh guru, untuk melaksanakan shalat jum'at berjamaah di mesjid. Dalam hal ini diperlukan upaya peningkatan pengawasan serta pengembangan imtak oleh pihak sekolah.

\section{b. Nilai-nilai Kebersamaan Siswa}

Nilai-nilai kebersamaan siswa telah cukup baik, terlihat adanya siswa senantiasa menerapkan hubungan (ukhuwah Islamiyah) dalam melakukan interaksi, baik saat KBM berlangsung maupun di luar KBM adanya kegiatan di sekolah, seperti bekerja sama dalam kegiatan kesiswaan dan saling membantu sesama siswa yang kesusahan.

Nilai-nilai kebersamaan siswa SMP menurut beberapa responden pada umumnya baik, terlihat dari beberapa prilaku siswa di sekolah dalam pergaulan teman-temannya, guru dan pegawai sekolah. Siswa dapat menghormati guru dan pegawai sekolah sebagai orang yang dituangkan di sekolah, dan siswa juga menghormati teman-teman sekelas maupun yang berbeda kelas. 
Rasa kebersamaan timbul pada diri siswa sekolah menengah karena guru telah mengajarkan kepada siswa untuk dapat menghargai orang lain. Siswa juga diajarkan membantu sesama, baik yang kurang mampu maupun yang mampu, orang yang terkena musibah, dan yang lainnya.

Siswa dapat bersama-sama saling membantu, tolong menolong dalam hidup beragama karena manusia sebagai mahkluk ciptaan Tuhan YME dianjurkan untuk saling membantu sesama. Karena adanya rasa saling menghormati, rasa saling menghargai dan saling tolong-menolong, sehingga dalam kehidupan siswa di sekolah dan di lingkungan masyarakat dapat terjalin kebersamaan dan kehidupan yang harmonis. Contoh kongkritnya dapat dilihat dari acara keagamaan yang diadakan sekolah seperti berbuka puasa, kegiatan jum'at takwa dan pesantren ramadhan.

\section{c. Nilai Saling Menghargai Siswa}

Nilai saling menghargai siswa telah cukup baik, hal ini terlihat dengan adanya sikap saling menghargai antar siswa yang tumbuh \& berkembang dengan baik, sehingga tidak terdapat dikotomi antar siswa yang memiliki latar belakang ekonomi atas maupun bawah. Indikasinya adalah tidak ada perselisihan sesama siswa yang mengarah ke anarkis dan terjaganya kerukunan dalam beragama.

Selanjutnya, nilai saling menghargai siswa berjalan dengan baik, sebahagian besar siswa masih mengerti dan memahami cara menghargai teman lain sekelas, sekolah dan alumni. Secara umum masih dikategorikan bagus, namun karena hubungan globalisasi dan budaya luar, tingkat individualisme cenderung meningkat. Nilai saling menghargai siswa cukup bagus, karena siswa di SMP terdiri dari strata ekonomi dan sosial yang berbeda tetapi dalam keseharian siswa tidak telihat perbedaan yang mencolok. Terlihat keakraban siswa antar kelas dan antar tingkat kelas serta tidak adanya geng-geng yang dibentuk siswa dalam pergaulannya. Nilai saling menghargai siswa cukup baik dapat dilihat dari pergaulan mereka sehari-hari yaitu tidak melecehkan teman yang kekurangan.

\section{d. Nilai Tanggungjawab Siswa}

Nilai tanggungjawab siswa cukup baik yaitu siswa selalu siap melaksanakan tugas yang bersifat kurikuler, selalu siap melaksanakan tugas yang bersifat ko-kurikuler seperti; memimpin doa setelah shalat berjamaah, memberikan kultum, menjadi pembawa acara, menghafal doa-doa, menghafal ayat-ayat Al Qur'an, siswa melaksanakan peraturan sekolah dan melaksanakan tugas-tugas yang di bebankan oleh sekolah 


\section{e. Nilai-Nilai Keamanan, Kebersiban, Ketertiban dan Keindaban}

Dari segi keamanan cukup terkendali, karena adanya penetapan piket guru, pembentukan seksi keamanan setiap kelas, dan adanya penjaga sekolah, dan juga adanya kerjasma dengan warga lingkungan sekolah. Kebersihan sudah cukup bagus karena keterlibatan siswa dalam kebersihan melalui piket perkelas, pemberdayaan petugas sekolah, pengadaan tong sampah ditiap kelas dan lingkungan sekolah, kemudian juga mempraktekkan K3 setiap minggu. Ketertiban cukup tertib karena penetapan tata tertib bagi guru dan karyawan sekolah, penetapan tata tettib bagi siswa melalui musyawarah dengan wali siswa. Keindahan sekolah oleh siswa melalui penghijauan, dan penanaman apotik hidup.

\section{f. Nilai-Nilai Hubungan Antar Siswa dengan Selurub Warga Sekolab}

Nilai-nilai hubungan antar siswa dan seluruh warga sekolah terjalin dengan baik. Hubungan antara siswa dengan guru, karyawan, satpam, dan seluruh majelis (warga sekolah) cukup menarik, karena berada dalam kompleks pendidikan. Hal ini terjadi karena adanya pembinaan yang berkesinambungan siswa dengan siswa dan karyawan serta guru sebagai pembina. Keadaan ini ditunjang dengan adanya kompetisi antara sekolah dengan mengadakan kompetisi olah raga. Di samping itu juga diadakannya kegiatan silaturahmi dan adanya kegiatan yang menyangkut peran serta seluruh warga sekolah. Meskipun hubungan dengan sesama warga sekolah sudah berjalan cukup baik hendaknya perlu ditingkatkan lagi demi pencapaian mutu pendidikan lebih baik.

Hubungan antara warga sekolah dan warga masyarakat dapat terjalin dengan baik, yang terlihat pada kegiatan peduli umat yang sudah dilaksanakan selama tiga tahun belakangan, berupa pemberian sembako kepada warga terdekat. Selain itu, sekolah juga selalu berusaha untuk mengadakan kegiatan peduli warga dengan diadakannya kegiatan: 1. Gerakan peduli umat yaitu pembagian sembako kepada siswa tidak mampu, panti asuhan terdekat dan masyarakat sekitar

2. Mengumpulkan zakat fitrah dan membagikannya untuk masyarakat sekoitar

3. Mengadakan kegiatan sedeqah qurban dan pelaksanaan qurban.

\section{Pengembangan Tataran Teknis}

Pada umumnya SMP yang diteliti telah memiliki tataran teknis dalam bentuk manifestasi budaya sekolah seperti : (1) struktur organisasi sekolah, (2) deskripsi tugas sekolah, (3) tata tertib guru, (4) tata tertib 
siswa, (5) sanksi siswa yang melanggar tata tertib sekolah, (6) program kerja dalam pembinaan keimanan dan ketakwaan siswa terhadap Tuhan, (7) program ekstrakulikuler yang dapat menumbuhkan kejujuran, kedisiplinan, rasa tanggung jawab dan rasa kesetiakawanan siswa, (8) peraturan dan kebersihan fisik sekolah, (9) strategi belajar dan pembelajaran yang mendorong siswa agar semangat belajar, dan (10) standar sistem pembelajaran yang harus diikuti guru maupun siswa.

\section{Pengembangan Tataran Sosial}

Kebijakan yang dikembangkan SMP dalam sosialisasi dan implementasi budaya sekolah adalah dengan membuat aturan-aturan yang jelas yang diberitahukan di kelas maupun sewaktu upacara atau pada peringatanperingatan hari-hari besar keagamaan. Mengadakan musyawarah sosialisasi budaya sekolah bersama orang tua siswa, mengadakan rapat kerja program sekolah dengan pengurus. Kemudian sekolah sangat mendukung hal-hal yang berkaitan dengan nilai-nilai budaya yang bernuansa islami seperti kegiatan kebersihan, seperti: Sabtu bersih, penerapan sangsi, pemberian penghargaan, kegiatan keagamaan, dan kegiatan perlombaan antar sekolah.

4. Pelembagaan Budaya Sekolah di Kalangan Siswa

Cara melembagakan budaya sekolah di kalangan siswa pada SMP adalah dalam bentuk institusional budaya sekolah (1) melalui pendidikan agama, (2) melalui poster, gambar ritual atau kaligrafi, (3) melalui kegiatan keagamaan seperti sholat berjamaah, tadarrus Al Qur'an dan pesantren kilat, (4) melalui pemberian wawasan mengenai fungsi manusia sebagai makhluk sosial yag diciptakan sebagai makhluk yang lemah dan membutuhkan orang lain, (5) melalui pembiasaan kedisiplinan sejak dini, (6) menumbuh-kembangkan rasa senang belajar dikalangan siswa, (7) menumbuhkembangkan rasa tanggung jawab siswa, (8) menumbuh-kembangkan rasa kejujuran siswa, (9) memperbanyak buku perpustakaan dan mengembangkan taman bacaan untuk siswa, dan (10) pemajangan motto atau semboyan keagamaan di tempat-tempat tertentu di sekolah.

\section{Evaluasi Budaya Sekolah}

Berkaitan dengan budaya sekolah yang berkembang mendukung pengembangan pembelajaran pendidikan agama Islam, maka pihak sekolah di SMP mendukungnya dengan cara melibatkan seluruh guru dalam kegiatan keagamaan, mengharuskan guru untuk mengaitkan 
materi pembelajaran dengan Al-Qur'a-Hadist dan melibatkan guru umum sebagai panitia/penguji program kegiatan keagamaan, $\mathrm{PHBI}$, pesantren kilat, dan bazar serta santunan bagi yang kurang mampu.

Budaya sekolah yang berkembang juga mendukung tingkat keimanan dan ketakwaan siswa melalui pesantren ramadhan, pesantern sabtuahad, infak mingguan (setiap hari jum'at), santunan fakir miskin dan yatim piatu, santunan beasiswa sekolah binaan, penetapan budaya salam antar guru, karyawan dan siswa, setiap guru dalam proses pembelajaran materi dikaitkan dengan keimanan dan ketakwaan, selanjutnya pihak sekolah dalam menyikapi perkembangan budaya yang masuk ke dalam sekolah selalu melakukan penyaringan agar budaya Islami mendukung tingkat keimanan dan ketaqwaan siswa, kemudian siswa dapat mengaplikasikannya sehari-hari yaitu dengan: shalat berjamaah, mengumpulkan infak, dan pengajian bersama.

Budaya yang berkembang mendukung lahirnya rasa tanggung jawab, kebersamaan, saling menghargai, kesetiakawanan, kedisiplinan dan gemar membaca di kalangan siswa melalui; program pembiayaan, pembentukan kelompok teman sebaya, penetapan jadwal kunjungan ke perpustakaan dan pemberian penghargaan bagi siswa dan guru yang rajin serta aktif membaca. Semua guru mengharapkan peserta didik, memiliki rasa tanggung jawab, menghargai, setia kawan, disiplin, baik di lingkungan sekolah maupun di rumah. Selanjutnya setiap bentuk budaya ada sisi lemahnya, ada yang positif dan negatif, akan tetapi pada prinsipnya budaya yang berkembang di sekolah harus mendukung bagi siswa.

Budaya sekolah yang berkembang juga mendukung hubungan personal siswa dengan seluruh warga sekolah agar berjalan baik yaitu hubungan personal antar siswa terjalin dengan baik, sehingga tercipta suasana kondusif, setiap siswa diwajibkan untuk selalu mengucapkan salam dan menghormati warga sekolah, dan bersikap santun, kemudian seluruh kegiatan yang telah di pergunakan berjalan dengan baik dengan melibatkan siswa dan warga sekolah.

Budaya sekolah yang berkembang juga mendukung $5 \mathrm{~K}$ (keamanan, kebersihan, ketertiban, keindahan dan kenyamanan sekolah) melalui salah satu program utama sekolah dalam peningkatan dan implementasi $5 \mathrm{~K}$ (keamanan, kebersihan, ketertiban, keindahan, keindahan, kenyaman). Melalui program $5 \mathrm{~K}$ dan jadwal piket, agar dapat dilaksanakan di dalam kelas dan di lingkungan sekolah. 


\section{KESIMPULAN}

1. Terdapat hubungan yang positif budaya sekolah terhadap motivasi belajar siswa.

2. Terdapat hubungan yang positif budaya sekolah terhadap hasil belajar pendidikan agama Islam siswa.

3. Terdapat hubungan yang positif motivasi belajar terhadap hasil belajar pendidikan agama Islam siswa.

4. Semangat siswa dalam menjalankan nilai-nilai keimanan dan ketakwaan, saling menghargai, kebersamaan, rasa tanggungjawab cukup baik.

5. Semua SMP yang diteliti telah memiliki tataran teknis dalam bentuk manifestasi budaya sekolah seperti : (1) struktur organisasi sekolah, (2) deskripsi tugas sekolah, (3) tata tertib guru, (4) tata tertib siswa, (5) sanksi siswa yang melanggar tata tertib sekolah, (6) program kerja dalam pembinaan keimanan dan ketaqwaan siswa terhadap Tuhan, (7) program ekstrakulikuler yang dapat menumbuhkan kejujuran, kedisiplinan, rasa tanggung jawab dan rasa kesetiakawanan siswa, (8) peraturan dan kebersihan fisik sekolah, (9) strategi belajar dan pembelajaran yang mendorong siswa agar semangat belajar, dan (10) standar sistem pembelajaran yang harus diikuti guru maupun siswa.

6. Kebijakan yang dikembangkan SMP dalam sosialisasi dan implementasi budaya sekolah adalah dengan membuat aturan-aturan yang jelas yang diberitahukan di kelas maupun sewaktu upacara atau pada peringatan-peringatan hari-hari besar keagamaan, mengadakan musyawarah sosialisasi budaya sekolah bersama orang tua siswa

7. Sekolah sangat mendukung dalam "budaya" terlebih yang erat kaitannya dengan nilai-nilai budaya Islami seperti kegiatan kebersihan sabtu bersih, penerapan sangsi, pemberian penghargaan, kegiatan keagamaan, dan kegiatan perlombaan antar sekolah.

8. Pelembagaan budaya sekolah di kalangan siswa SMP dilakukan melalui: (1) pendidikan agama, (2) melalui poster, gambar ritual atau kaligrafi, (3) kegiatan keagamaan seperti sholat berjamaah, tadarrus Al Qur'an dan pesantren kilat, (4) pemberian wawasan mengeni manusia sebagai makhluk sosial yag diciptakan oleh Tuhan sebagai makhluk yang lemah dan membutuhkan orang lain, (5) pembiasaan kedisiplinan sejak siswa dini, (6) menumbuhkembangkan rasa senang belajar dikalangan siswa, (7) menumbuhkembangkan rasa tanggung jawab siswa, (8) menumbuhkembangkan rasa kejujuran 
siswa, (9) memperbanyak buku perpustakaan dan mengembangkan taman bacaan untuk siswa, dan (10) pemanjangan motto atau semboyan keagamaan di tempat-tempat tertentu di sekolah.

9. Budaya sekolah yang berkembang juga mendukung tingkat keimanan dan ketaqwaan siswa melalui pesantren ramadhan, pesantern sabtuahad, infaq mingguan (setiap hari jum'at), santunan fakir \& miskin \& yatim piatu, santunan beasiswa sekolah binaan, penetapa budaya salam antar guru, karyawan \& siswa, setiap guru dalam proses pembelajaran materi dengan keimanan dan ketaqwaan.

\section{SUMBER BACAAN}

Ahmadi, Abu dan Widodo Supriyono (1991): Psikologi Belajar. Jakarta, Penerbit Rineka Cipta.

Direktorat Pendidkan Menengah Umum, Direktorat Jenderal Pendidikan Dasar dan Menengah, Departemen Pendidikan Nasional, Pedoman Pengembanagan Kultur Sekolah, Penerbit School Reform 01, Tahun 2002

Fred, Luthans. 1995. Organization Behavior. Singapore: Mc Graw-Hill.

Hodge, BJ. dan William P. Anthony (1991): Organization Theory. Boston: Allyn and Bacon, Inc.

James, H. Donnely Jr. at al. (1984): Fundamentals of Management. Texas, Business Publication, Inc.

Michael, Amstrong (1999): Mancjemen Sumber Daya Manusia, terjemahan Haryanto, Jakarta, Gramedia.

Nana, Syodih Sukmadinata, dkk (2006): Pengendalian Mutu Pendidikan Sekolah Menengab: Konsep, Prinsip dan Intrume. Jakarta: Penerbit Aditama.

Nancy. J. Adler, at al. (1995): Cross-Cultural Management. London, ButterwortHeinemann Ltd.

Pabundu Tika, Moh. (2006): Budaya Organisasi dan Peningkatan Kinerja Perusahaan, Jakarta: Penerbit: Bumi Aksara.

Theodore, T. Herbert (1981): Dimensions of Organization Behavior, Macmillan Publishing co.,Inc.

Umaedi. 2006. Manajemen Peningkatan Mutu Berbasis Sekolah; Sebuab Pendekartan Baru dalam Pengelolaan Sekolah untuk peningkatan Mutu., www Depdiknas, go.,id., Diakses 20 Februari.

Undang-undang Sistem Pendidikan Nasional, Nomor 20 Tahun 2003 